TJTMI Volume 1, Number Issue I (Spring 2022), pp. 91-98

\title{
Christ in Creation
}

\author{
Dr. John F. MacArthur \\ Chancellor of The Master's University and Seminary \\ Pastor-Teacher of Grace Community Church
}

Featured Article: The following essay is adapted from John MacArthur's talk at the first annual TheoTech Conference at The Master's University on October 30, 2021 and is used by permission.

According to a recent article from Cornell University, astronomers have confidently affirmed that the universe came into existence 13.8 billion years ago-not 13.9 , but 13.8 billion years ago-and subsequent to that came human life by chance [Gla21, $\mathrm{C}^{+}$20, Goh21]. The odds of human life appearing after the Big Bang have even been marked as one in a trillion trillion. Only after the earth came to exist did all the creatures appear. Finally, the humans evolved, but only after the exact sperm and egg cell evolved to generate a human with the DNA sequence that eventually brought us all into existence. Originally the chance of this was stated as one in 250 million for the sperm alone apart from the egg, and that needed to happen constantly and incessantly in an unbroken chain of millions of generations of your ancestors until it happened again by chance and created you.

Obviously, such a scenario stretches and strains credibility beyond the breaking point. It's equal to stupidity. Evolution is built on myth, and the dominant myth of evolution is chance. Someone once said, "Chance is the new pillow for science to lie down on," but the truth is that irrational explanation would keep a rational person awake all night.

\section{The Myth of Chance}

Reflecting on "the myth of chance" is helpful. Chance was once a word restricted to describing mathematical probability. It was later broadened to include any unpredictable event, any kind of probability or coincidence. But be clear: chance in itself is nothing. It is a word to describe 
something else-other forces, other realities. Evolution has transformed chance into a force and a power. It has been elevated to be the greatest force in the universe; it is the power that created everything. Chance took nothing and turned it into everything. It took chaos and turned it into order. It took irrationality and turned it into coherence. It took "causelessness" and produced all effects. In fact, in an evolutionary world, chance is the creator. But this is, of course, logic and reason abandoned, which leaves only myth. The essence of myth cosmology is random, mindless nothing being the power that produces what is fixed law and rational reality. And the enemies of myth cosmology are empirical data and reason, which is the essence of pure science. If you neutralize either data or reason then you have enthroned myth, and that is exactly what scientists have done. They have created a hopeless schizophrenia.

Why does rational man do this? A twentieth-century Hungarian Jewish author named Arthur Koestler, who committed suicide with his third wife, offers this famous quote: "As long as chaos dominates the world, God is an anachronism" [Koe41]. And that's the point. Getting rid of God leads to a kind of mental suicide that may lead to actual suicide. If chance is sovereign, God is not. And if God is not sovereign, God is not God by definition. But chance is not God, nor is it a force of any kind. Chance is nothing. It has no power to do anything. It can't be the cause of anything. It can't be the power behind anything. It can't be the force that produces anything. Yet modern science, denying this truth, attributes incomprehensible power to chance. This hocus-pocus ignores law, science, logic, and reason, and it rejects the creative Latin phrase ex nihilo, nihilo fit. Out of nothing, nothing comes.

When scientists attribute instrumental means to chance, they have affirmed absurdity. George Wald, a 1967 Nobel laureate, offered a telling quote from this perspective: "Given so much time, the 'impossible' becomes possible, the possible probable, and the probable virtually certain. One has only to wait: time itself performs the miracles" [Wal54]. So that's how chance operates. Chance is a force that operates if there's enough time. That in itself is another absurdity postulated by a man who was hailed as one of the great scientists in the world.

Quantum theory is a good place to see the folly of chance as a creative force. In 1900 German physicist Max Planck presented the idea that energy comes in discrete units called quanta. In 1927 Warner Heisenberg, another German physicist, found that when a photon strikes an atom, boosting an electron into a higher orbit, the electron moves from the lower to the upper orbit simultaneously without having traversed the intervening space. The electron simply ceases to exist at one location and simultaneously appears in another. Out of that came the "quantum leap." It goes out of existence here, appears there, and never traverses the space in between. How is that possible? What is the power that makes that happen? There is no scientific explanation, hence the confusion of being able to explain it. In truth, the reality that explains this is found in what the Scripture says about Christ who "upholds all things by the word of His power" (Hebrews 1:3). There is a divine person who holds all atomic energy together. God is in the gaps. Chance and time can't produce anything. (In fact, how can there 
even be time without anything else?)

Early computer scientist John von Neumann once imagined what became known as the von Neumann machine. He said that the perfect machine would be self-generating, selfrepairing, and self-reproducing, but no one could produce it because it would be too complicated. However, that's exactly what every living cell is: self-generating, self-repairing, and self-reproducing, and God has made trillions of them in each human body. Also think back to the Middle Ages when theology was called "the queen of the sciences"; that is, theology ruled science. Theology provides the only rational basis for the existence of anything, and Genesis 1-3 is the rational account of creation by the Creator Himself. Everything had to start with the uncreated God. Without God, all explanations are varieties of the absurd. In Exodus 3 God says, "I AM THAT I AM," indicating that there was never a time when God did not exist. He is self-existent, self-sufficient, and sovereign. And in Genesis where the I AM acts to create, there is a simple and rational declaration: "In the beginning, God created the heavens and the earth" (Genesis 1:1).

Anthropologist Herbert Spencer, who died in 1903, identified five categories of the knowable: time, force, action, space, and matter [Spe67]. Everything, he claimed, fits into one of those five categories. But long before Spencer, Genesis 1:1 made the declaration of those very categories: "In the beginning" (time), "God" (force), "created" (action), "the heavens" (space), "and the earth" (matter). So the first verse of the Bible covers all the categories. There is only one account of the creation, and that is the verbal testimony of the Creator-His spoken intelligent words. This is far from the ridiculous notion that nobody times nothing equals everything. It is far from the absurdity that chance, which is nothing, was the power of creation. And it is far from the irrational notion that time existed before there was anything. There's only one reasonable reality, and that is the fact that the eternal God is the Creator.

\section{In the Beginning Was the Word}

The creation account in Genesis is further detailed in John 1:1-5 [LSB21]:

In the beginning was the Word, and the Word was with God, and the Word was God. He was in the beginning with God. All things came into being through Him, and apart from Him nothing came into being that has come into being. In Him was life, and the life was the Light of men. And the Light shines in the darkness, and the darkness did not overtake it.

This revelation introduces something highly significant. The Creator is identified as "the Word," which appears three times in the first verse: the Word was God, was with God, and was in the beginning with God. Moreover, all things were created by the Word, in the Word was life, and "the life was the Light of men." There is no explanation in this text as to why the phrase "the Word" is used the way it is, because it was already familiar to the readers of the New Testament—both to Jews and Greeks. Greeks were familiar with the term logos (word), 
which some identified as the supernatural, impersonal power and mind behind creation. They recognized that information was essential to creation. And the Jews knew what the Old Testament said. Consider Psalm 68:32-33, for instance: "Sing to God, O kingdoms of the earth, sing praises to the Lord, to Him who rides upon the highest heavens...behold, He speaks forth with His voice, a mighty voice." God created with His voice, with words. Psalm 29:3-11 further says [LSB21]:

The voice of Yahweh is upon the waters; the glory of God thunders, Yahweh is over many waters. The voice of Yahweh is powerful, the voice of Yahweh is full of splendor. The voice of Yahweh breaks the cedars; indeed, Yahweh breaks in pieces the cedars of Lebanon. He makes Lebanon skip like a calf, and Sirion like a young wild ox. The voice of Yahweh hews out flames of fire. The voice of Yahweh causes the wilderness to tremble; Yahweh causes the wilderness of Kadesh to tremble. The voice of Yahweh makes the deer to calve and strips the forests bare; and in His temple everything says, "Glory!" Yahweh sat enthroned over the flood; indeed, Yahweh sits as King forever. Yahweh will give strength to His people; Yahweh will bless His people with peace.

The eternally existing One spoke everything into existence by His words and sustains it all by His words. This is also reiterated in 2 Samuel 22:14: "The Lord thundered from heaven, and the Most High uttered His voice." These passages and many more show that the word of the Lord is a significant Old Testament theme. The word of the Lord came again and again because God spoke. In other words, God is a speaking God, which means He is intelligent, and $\mathrm{He}$ is a communicator. The word of the Lord was from God; it was His communication coming with power to bring into existence whatever His will desired.

Thus, we know by this that the Creator is a communicator. The Creator possesses reason, cognition, massive intelligence, wisdom, and incomprehensible power. In ancient times, common people in the Greek world understood the logos as a force behind what existed, and the Jews knew it was the word of the Lord behind all that was created. The apostle John presents the truth that the creative power, the creative force, and the creative wisdom is not an impersonal reality, but is the personal God who came into the world in the man Jesus: "The Word became flesh, and dwelt among us, and we saw His glory, glory as of the only begotten from the Father, full of grace and truth" (John 1:14). So, God spoke and all that exists came into existence by His words.

This foundational point is even observable from the vantage point of science because what precedes the creation and function of anything is information. Wallace B. Henley has written an interesting book on artificial intelligence in which he asks the question posed in the book's title: Who will rule the coming gods? The thesis of the book is that godless society will create machines more intelligent than a person. Those machines will take the place of God. So he asks, "Who will rule the coming gods of artificial intelligence?" The book also considers the role that information plays in bringing anything into existence. Here is an illustration [Hen21]:

...during the Second World War, great effort was made to break the Enigma code used by the Germans to pass secret information. A code-breaking project was established at Bletchley Park 
in Buckinghamshire, England. The goal of Alan Turing and his team was to break the code the Germans changed daily through the Enigma device which could configure messages in 150 million million million ways.

The Bletchley machines existed only because the information coded and transmitted through Enigma already existed. Thus, in the sequence of data processing, there was the primacy of information. The information called forth the existence of the machines. The devices and systems that Bletchley made didn't initiate the data but processed and made sense of it.

The machines existed because the information was already there.

By the same principle, artificial intelligence can accumulate and process data and even enlarge its knowledge base. But it does so not by creating new bits of information but by gathering the information already present. The AI machines exist because the information exists.

Henley further writes:

Again, all of this makes even more stunning the Bible's revelation that "in the beginning was the Logos," and that "nothing was made that was made without the Logos" (John 1:1). Usually, the Greek logos is translated in the English Bible as "word," but that term does not capture the scope of the meaning of the Greek logos. Heraclitus, for example, used logos to refer to "the ordering principles of the universe." [Gra]

But what was it that had to be ordered, if not the innumerable bits of quanta or information? And what was the origin of the information?

Imagine the engineers building artificial intelligence machines. The technicians program the information into the box based on what they and others know in their own brains. Information is ultimately intelligence, and intelligence arises from minds with the capacities of reflection and reason, which means "person."

Therefore, if information exists prior to creation, if information is intellectual data known in a mind, and if a reasoning mind is an attribute of person, then who is the Person who exists prior to the universe who possesses logos and is logos and infuses into the void the information that will bring the cosmos into existence?

The answer is God. Henley then goes on to say, "Remember that in the absence of a Creator, the skeptic would have to believe that the universe created itself, having first created the information by which it created itself." And one final paragraph states:

Therefore, the AI phenomenon gives us a "backdoor" proof, or apologetic, of God's existence. As the first AI machine could not have brought itself into existence but required a creator acting on the information in his or her mind, so the "vast quantum computer" that is the universe could not have brought itself into existence without something "transcendent" (other) to itself who could infuse it with information.

When the apostle John said what he said about the Word, he was saying something very profound: "the Word," the information, had to come first. "In the beginning was the Word" means He existed in the beginning, and moreover "the Word was with God, and the Word was God." He was in the beginning with God. God is immutable, pure, eternal being. He is not 
becoming because He never changes, while all His creatures constantly change. Eternal God is just that: eternal. And He has a mind that is a reasonable mind and a revealing mind. $\mathrm{He}$ speaks. We see then in John 1:1 that everything that was made was made by the Word-the incarnate Word is the God who spoke everything into existence, as in Genesis 1.

\section{Christ in Creation}

So, looking at John 1:1-5 a little more closely, there are three attributes that God declares about the Word. Three basic realities about God are revealed in this section [Maco6]. First is His preexistence in verse 1: "In the beginning was the Word." The phrase "in the beginning" refers to Genesis 1:1 where at creation the Word was already in existence. The eternal Son of God is not a created being. He was there in the beginning when everything was created (John 1:2). This describes eternal existence before creation-the eternal preexistence of the Son who is called the Word. Said differently, the Word didn't become anything because He always was. The One who always was took on true humanity in His incarnation. But in His nature, He is pure, everlasting, and eternal being. That is why His name is I AM. In John 8:58 Jesus said, "Before Abraham was, I am," and Colossians 1:17 says of Christ, "He is before all things, and in Him all things consist." He was there with God in the beginning, and this declares His preexistence.

Second, John also points to His coexistence in verse 1: "He was God." In His preexistence the Word was God. This is a very powerful Greek expression meaning "face to face with God," which is to say He has intelligent personal fellowship on an equal level. Scripture affirms the deity of the Lord Jesus Christ. He is truly God, not an attribute of God or an emanation from God. He is not a creation of God, but He is God and at the same time a unique person who was with God. As Paul said to the Colossians, "In Him all the fullness of Deity dwells" (Colossians 2:9).

So the Word - the intelligent, divine, triune Being who created everything-necessarily preexisted His creation, because intelligence has to preexist the information required for the creation of anything. His preexistence is His eternality. Secondly, He is God, fully God, truly God, and with God. His coexistence is His equality. And thirdly in John 1:3-5 there is the declaration of his self-existence: "All things came into being through Him, and apart from Him nothing came into being that has come into being." That's true because in Him was life. He is self-existing - the uncreated One. "Jesus Christ is the same yesterday, today, and forever" (Hebrews 13:8). All things came into being because of Him. Notice that is a positive declaration. It is a simple, clear, and flawless proof of the eternal nature of the Lord Jesus as God. This doesn't deny God as Creator, and it doesn't deny the Spirit as Creator. The whole Trinity is involved in the creation. For further affirmation, a negative declaration follows the positive one: "Apart from Him nothing came into being that has come into being." Not even one thing 
exists that He didn't create, and such is the only explanation that makes any sense because information must proceed creation. If in the beginning there is nothing, then "nothing" cannot generate the information needed to create. It is insane to deny that reality.

In verse 4 John also says of the Word: "In Him was life." Life proceeded from Him. Everything that lives receives life from Him. This is a massive statement. "Life" here is the Greek word $z \bar{o} \bar{e}$ not bios. It refers to all kinds of life-not just biological life but life in every sense, both physical and spiritual. He has life in Himself. He didn't receive life. He wasn't given life. All life comes from Him. This self-existence is referred to by theologians as the aseity of God and of Christ. The creation of anything requires either a self-existent God, or a self-existent source of information without a mind and without a person. The latter is impossible. Out of nothing cannot come the information that creates everything because nothing is nothing. The truth, the reality, the information has to preexist the creation. Self-existent, eternal Deity spoke creation into existence. Again, notice that everything in the created world is becoming. But God is not becoming; God is being. He is pure, eternal being. Everything else is changing, and this distinguishes the creation from the Creator. Such is the fundamental reality of all reality: "In the beginning, God created the heavens and the earth."

John further writes in verse 4 of chapter 1, "the life was the Light of men." While some distinction obviously exists between life and light, here they are inseparable: life becomes the Light. The life is the manifestation of divine truth. The Light displaced the dark void with truth. God's life shines like holy light into the darkness of sin, and "the darkness did not comprehend it" (verse 5). Literally, it did not overpower it. And we know the darkness did not overpower it because we have received the Scripture- the revelation of God as to the truth of the life and the Light.

\section{Summary}

So the role that Christ played in creation is stated directly in John 1:1-5. By just touching lightly on this text you recognize that it affirms that there must be information before creation. Information means intelligence, intelligence means a mind, a mind means a person, and a person has to be someone who is preexisting-someone who is transcendent. That points to God and God alone.

There is a reason why Genesis $I$ is under attack: if God can be eliminated at the very opening of Scripture, then rejectors have reason to discredit all the rest. So, John gives us an unparalleled look in just those few verses at not only the deity of Christ but also the fact that $\mathrm{He}$ is the divine revelation that brought everything into existence. And in the revelation of God in creation and in the spiritual realm, He has provided the Light of salvation that extinguishes the darkness. So the creation account cannot be separated from the gospel. The Light of men is the gospel. The Light shining in the darkness is the light shining against the 
blackness of sin. The same One who created everything is the One who shines gospel light into the darkness.

You wouldn't want to tamper with Genesis 1, nor would you want to tamper with John 1. These two accounts give us all we need to know. God created by speaking. Christ, the Word, created everything that existed by speaking. He spoke, and life came into existence-including spiritual life, which comes like light in the darkness to deliver men from sin and death and judgment.

\section{Bibliography}

$\left[\mathrm{C}^{+}{ }_{20}\right.$ ] Steve K. Choi et al. The Atacama cosmology telescope: a measurement of the cosmic microwave background power spectra at 98 and 150 GHz. Journal of Cosmology and Astroparticle Physics, 2020(12):045, 2020.

https://doi.org/10.1088/1475-7516/2020/12/045.

[Gla21] Linda B. Glaser. Astronomers agree: Universe is nearly 14 billion years old. Cornell Chronicle, 2021. Available online: https://astro. cornell.edu/ astronomers - agree-universe-nearly-14-billion-years-old (accessed on 30 October 2021).

[Goh21] Chelsea Gohd. Astronomers reevaluate the age of the universe. Space.com, 2021. Available online: https://www. space.com/universe-age-14-billion-years-old (accessed on 30 October 2021).

[Gra] Daniel W. Graham. Heraclitus (fl. c. 500 B.C.E.). Internet Encyclopedia of Philosophy. Available online: https://iep.utm. edu/heraclit/ (accesssed on 30 October 2021).

[Hen21] Wallace B. Henley. Who Will Rule The Coming 'Gods'? The Looming Spiritual Crisis Of Artificial Intelligence. Vide Press, Washington DC, 2021.

[Koe41] Arthur Koestler. Darkness at Noon. Scribner, New York, 1941.

[LSB21] Legacy Standard Bible. Three Sixteen Publishing, 2021.

[Maco6] John F. MacArthur. John 1-11: The MacArthur New Testament Commentary. Moody Press, Chicago, IL, 2006.

[Spe67] Herbert Spencer. First Principles. Williams and Norgate, London, 1867. 2nd ed.

[Wal54] George Wald. The origin of life. Scientific American, 191:44-53, 1954. 